\title{
Digitale ondersteuning voor urine- incontinentie bij vrouwen; mogelijkheden en beperkingen
}

S.M. Kelders, M.J.F.M. de Bruin en J.E.W.C. van Gemert-Pijnen ${ }^{1}$

\section{Samenvatting}

Onderbehandeling is een probleem bij urine-incontinentie bij vrouwen. Digitale ondersteuning bij het stellen van de juiste diagnose en het geven van behandeladviezen lijken mogelijkheden te bieden om de zorg voor de patiënt efficiënter en beter bereikbaar te maken. Daarnaast kan het bieden van zelfzorgmogelijkheden via een online applicatie taboedoorbrekend werken en dienen als een eerste stap in de behandeling. Via de huisarts kan de uroloog worden ingeschakeld wanneer zijn specialistische zorg vereist is.

Trefwoorden: urine-incontinentie bij vrouwen, onderbehandeling, digitale ondersteuning, eHealth, triage

\section{Summary}

Web-based support in female urinary incontinence; opportunities and limitations

Under treatment is a problem in female urinary incontinence. Web-based support in making the right diagnosis and giving treatment advice, poses an opportunity to offer more efficient and attainable care. Furthermore, offering self-care opportunities through a web-based application may prove taboo breaking and may serve as a first step in treatment. When specialist care is needed, the urologist can be involved through the general practitioner.

Keywords: Female Urinary Incontinence, Undertreatment, Web-based, E-Health, Triage

\section{Introductie}

Urine-incontinentie (UI) bij vrouwen komt veel voor. $^{1-4}$ In Nederland blijkt volgens een studie van Vandoninck et al. dat tot $46 \%$ van de getrouwde vrouwen last heeft van UI. ${ }^{5}$ Het is bekend dat er sprake

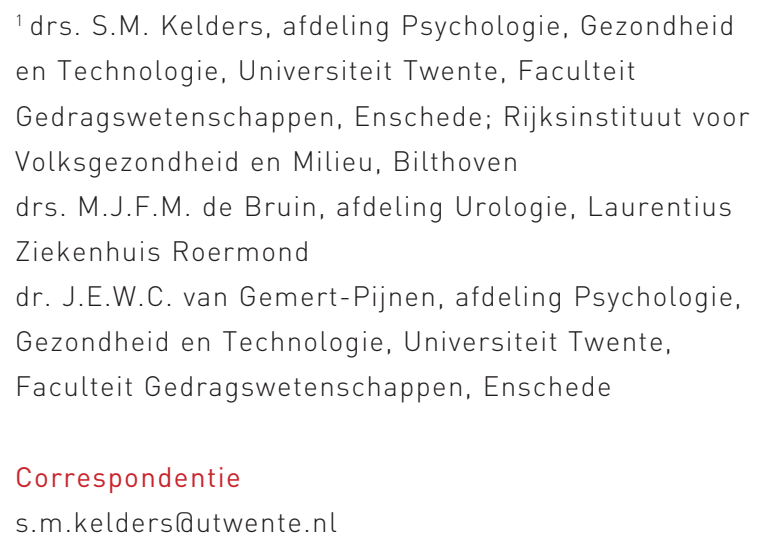

is van een forse onderbehandeling van deze aandoening, ${ }^{1,6-7}$ ondanks dat er effectieve behandelingen zijn. Er is een aantal redenen voor deze onderbehandeling aan te wijzen. Ten eerste speelt schaamte een belangrijke rol; schaamte zorgt ervoor dat vrouwen minder snel op zoek gaan naar professionele hulp..$^{8-9}$ Daarnaast zorgt onbekendheid met de aandoening en mogelijke therapieën ervoor dat veel vrouwen de hinder van hun aandoening accepteren als iets wat bij het ouder worden hoort of iets wat lastig is, maar waar je mee moet leren leven, omdat er niets aan te doen valt. ${ }^{10-11}$ Verder ligt een verklaring voor onderbehandeling in het niet kunnen vinden van de juiste hulp door onduidelijke voorlichting. ${ }^{8}$ Uit onderzoek komt ook naar voren dat huisartsen het moeilijk vinden om adequate zorg te verlenen. ${ }^{12-13}$ In plaats van het geven van advies, therapie en een eventuele doorverwijzing, wordt vaak aan symptoombestrijding gedaan met behulp van incontinentiemateriaal.

Onderzoek van Van Gemert-Pijnen et al. reikt een aantal mogelijkheden aan voor het voorkómen van deze onderbehandeling. ${ }^{8}$ Ten eerste er is adequate informatie nodig over de oorzaken van de aandoening en mogelijke behandelingen. Ten tweede, voor adequate hulp is het belangrijk om gerichte informatie te verschaffen over de mogelijkheden die de beroepsgroep 'urologen' kan bieden voor zorgverlening. Er is namelijk een verouderd beeld van wat een uroloog doet en kan; urologen worden gezien als de 'loodgieters van de vergrijzing. ${ }^{14-15} \mathrm{Bij}$ het publiek zorgt dit beeld ervoor dat de kloof tussen patiënt en uroloog erg groot is en dat potentiële patiënten minder snel hulp zoeken bij de uroloog. Ook huisartsen zijn slecht bekend met de mogelijkheden van urologie. De huisarts blijkt eerder een barrière voor het vinden van de juiste hulp dan een eerste contact voor de juiste behandelroute. Een manier om de weg naar de juiste urologische zorg te vergemakkelijken, is door gebruik te maken van digitale media die de bereikbaarheid van zorg vergroten, de huisarts ondersteunen en de uroloog voorzien van adequatere behandelinformatie.

In deze studie gaan we na hoe de kloof tussen patiënten en uroloog verkleind kan worden via digitale ondersteuning voor UI gericht op:

- verbetering van de informatievoorziening aan pati- 
enten over UI, behandelmogelijkheden en zelfzorg;

- verbetering van de bereikbaarheid van urologische zorg voor vrouwen met UI;

- verbetering van de zichtbaarheid van de uroloog als specialist bij de huisarts.

Er is gekozen voor digitale ondersteuning van UI aangezien deze problematiek omvangrijk is en er een applicatie beschikbaar is voor verbetering van de afstemming tussen eerstelijns- en tweedelijnszorg via zelfzorg en gerichte doorverwijzing. ${ }^{1-5}$ Deze applicatie kan met behulp van een vragenlijst onderscheid maken tussen verschillende typen van UI bij vrouwen. Aan de hand van deze applicatie kan worden onderzocht of de applicatie de zorg beter bereikbaar maakt, adequate informatie verschaft en de zichtbaarheid van de uroloog bevordert.

\section{Onderzoeksmethode}

Er is gebruikgemaakt van kwalitatief en kwantitatief onderzoek. Kwalitatief is de visie van experts onderzocht, de urologen die gebruikmaken van de applicatie. Op deze manier worden de mogelijkheden en beperkingen van digitale ondersteuning in kaart gebracht. De patiëntervaringen met de applicatie zijn via een kwantitatief onderzoek in beeld gebracht.

\section{Beschrijving van de applicatie}

De applicatie die als casus wordt gebruikt ('Mediarts') kan onderscheid maken tussen verschillende typen UI bij vrouwen. De gebruikster vult een onlinevragenlijst in, bestaande uit 44 diagnostische vragen (zoals: 'Treedt ongewild urineverlies op bij hoesten, niezen of lachen?'). De antwoorden op deze vragen worden met behulp van algoritmen omgezet in een voorspelling van de diagnose. Leidraad voor de ontwikkeling van deze algoritmen waren de richtlijnen van de $\mathrm{Ne}$ derlandse Vereniging voor Urologie (NVU) en van de European Association of Urology (EAU). Ter optimalisatie van de resultaten zijn deze algoritmen vervolgens ingebouwd in een neuraal netwerk. De applicatie is gevalideerd als diagnostische test via multicenter klinisch onderzoek en blijkt een positief voorspellende waarde te hebben van $90 \%{ }^{16-17}$ Verder blijkt uit onderzoek dat de applicatie ongecompliceerde zuivere stressincontinentie kan identificeren, waardoor het aantal invasieve urodynamische onderzoeken, afhankelijk van de vigerende indicatie, met maximaal $12 \%$ kan worden gereduceerd. Wanneer de applicatie in combinatie met een mictielijst wordt gebruikt, kan dit percentage stijgen tot $36 .{ }^{18}$

$\mathrm{Na}$ het invullen van de onlinevragenlijst volgt automatisch de voorspelde diagnose (uitgesplitst in 'zuivere stress', 'gemengd met nadruk op stress', 'gemengd', 'gemengd met nadruk op urge' en 'zuivere urge') en de ernst van de klacht. Daarnaast wordt een getailord ad- vies op basis van de richtlijnen van de NVU en EAU gegeven met daarin:

- risico- en complicerende factoren (ter verhoging van de patiëntveiligheid);

- conservatieve behandelingen en leefstijladvies (als basisbehandeling);

- advies voor uitgebreidere diagnostiek en behandeling wanneer de basisbehandeling onvoldoende effect laat zien.

Er zijn 2 versies, namelijk een met en een zonder zelfzorgmodule. De versie zonder zelfzorgmodule wordt gebruikt op diverse urologiepoliklinieken in Nederland en is gratis. De versie met zelfzorgmodule is tegen betaling beschikbaar (de kosten worden door een aantal zorgverzekeraars vergoed). De vragenlijsten van beide versies zijn identiek, behalve een vraag in de zelfzorgmodule over de moeilijkheid van het invullen van de vragenlijst. Ook de inhoud van de adviezen is identiek; in de zelfzorgversie is het taalgebruik echter afgestemd op de patiënt.

Alle informatie die in de zelfzorgmodule wordt ingevoerd, wordt opgeslagen in een database, uitgezonderd de persoonlijke data. Naast de voorspelde diagnose, geeft de database informatie over de leeftijd en bodymass index $\left(\mathrm{kg} / \mathrm{m}^{2}\right)$ van de gebruikster. Daarnaast wordt de tijd die nodig was voor het invullen van de vragenlijst opgeslagen, en de tijd en datum van het gegenereerde advies.

\section{Kwalitatief onderzoek: ervaringen van experts met digitale ondersteuning}

Om de ervaringen van urologen met digitale ondersteuning te onderzoeken, werden er semigestructureerde interviews gehouden met 5 experts (urologen die op de poli gebruikmaken van de applicatie). Er werd gebruiktgemaakt van een convenience sample, waarbij 5 urologen van verschillende ziekenhuizen bereid zijn gevonden om deel te nemen aan het onderzoek. De respondenten ontvingen geen compensatie voor deelname. De interviews werden afgenomen door dezelfde onderzoeker en duurden 30-45 minuten. Ze werden opgenomen met een audiorecorder en verbatim uitgeschreven. Voor de analyse werd gebruikgemaakt van de inductieve methode, waarbij thema's en categorieën vanuit specifieke observaties naar voren komen. ${ }^{19}$ De interviews gingen niet alleen in op de ervaringen van de urologen met de 'Mediarts'-applicatie, maar ook op de mogelijkheden en beperkingen van digitale ondersteuning bij vrouwen met UI in het algemeen. Het interviewschema bevatte de volgende onderdelen: 1) de 'Mediarts'-applicatie die in de zorg wordt gebruikt, waarbij het ging om het doel waarmee de applicatie werd gebruikt, het proces, de invloed ervan op de zorg en de verbeterpunten die werden gezien, 2) de mogelijkheden van de applicatie in de eerstelijnszorg, waar- 
bij werd ingegaan op de doelen, de doelgroep, de eisen en beperkingen en 3) de zelfzorgmodule, met vragen over de mogelijkheden, de doelgroep die nagestreefd zou moeten worden en de beperkingen en eisen van een zelfzorgmodule.

\section{Kwantitatief onderzoek: ervaringen van patiënten met digitale ondersteuning}

Het kwantitatieve deelonderzoek was gericht op het onderzoeken van de ervaringen van patiënten met de zelfzorgmodule. Gebruikers van de zelfzorgmodule konden, direct nadat ze de voorspelde diagnose en het advies voor hun klacht hadden ontvangen, via een link deelnemen aan het onderzoek. De link bracht ze bij een online survey waarin de volgende aspecten werden gemeten:

- welke acties zijn al ondernomen om de klachten te verminderen;

- plannen naar aanleiding van de verkregen voorspelde diagnose en het advies;

- beoordeling van de zelfzorgmodule op usability en kwaliteit van de zorg die wordt geleverd.

Usability (de mate waarin respondenten de applicatie als gebruiksvriendelijk ervaren) werd gemeten met 20 items op een vijfpunts Likert-schaal ( 1 = zeer negatief; $5=$ zeer positief) gebaseerd op onderzoek van Brooke et al. en Lewis et al. ${ }^{20-21}$ De vragen waren ingedeeld in 3 subschalen: Algemeen (bijvoorbeeld: 'Ik ben goed geïnformeerd over de (on)mogelijkheden van het zelfzorgprogramma.'), Vragen (bijvoorbeeld: 'De vragen die gesteld werden zijn begrijpelijk.') en de subschaal Advies (bijvoorbeeld: 'De manier waarop het advies wordt gepresenteerd is duidelijk.'). Kwaliteit van zorg werd gemeten met 17 items op een vijfpunts Likertschaal ( 1 = zeer negatief; 5 = zeer positief) gebaseerd op het werk van Donabedian en het Institute of Medicine. $^{22-23}$ Ook hier waren 3 subschalen, namelijk: Vragen (bijvoorbeeld: 'De antwoordmogelijkheden zijn volledig.), Diagnose (bijvoorbeeld: 'De verkregen diagnose is betrouwbaar.') en Advies (bijvoorbeeld: 'Het verkregen advies is op mijn probleem toegesneden.'). De antwoorden op de online survey werden via het tijdstip (datum en tijd) van het ontvangen advies van de zelfzorgmodule gekoppeld aan de gegevens uit de database van de zelfzorgmodule.

Aan het einde van de survey konden de respondenten aangeven of ze een uitnodiging via e-mail wilden ontvangen voor een follow-upvragenlijst na 6 weken. In deze vervolgvragenlijst werd ingegaan op de acties die de respondenten daadwerkelijk hadden ondernomen naar aanleiding van het advies. De deelnemers aan het onderzoek kregen geen compensatie voor deelname.

\section{Resultaten}

\section{Kwalitatief deelonderzoek onder experts}

\section{Inbedding applicatie in de zorg}

Uit de interviews met urologen bleek dat de manier waarop de applicatie op de polikliniek wordt gebruikt, verschilt per ziekenhuis. Over het algemeen wordt de online vragenlijst van de applicatie in combinatie met andere vragenlijsten afgenomen door de (continentie) verpleegkundige. In sommige ziekenhuizen worden er op basis van de diagnose uit de applicatie (en andere vragenlijsten) door de verpleegkundige vervolgafspraken en onderzoeken gepland met de patiënt. De uroloog wordt dan tijdens het eerste bezoek van de patiënt niet geconsulteerd. In andere ziekenhuizen wordt de informatie uit de applicatie en de andere vragenlijsten doorgegeven aan de uroloog die dan de vervolgstappen plant. Dit betekent dat de applicatie in de zorg nog onduidelijk is ingebed. Enerzijds wordt de applicatie gezien als een extra kwaliteitsmiddel voor doorverwijzing door verpleegkundigen naar gerichte zorg, anderzijds wordt de applicatie gezien als een extra controle op de diagnose door de expert. Bovendien worden diverse instrumenten door elkaar gebruikt (online- en conventionele vragenlijsten voor de diagnostiek). De geïnterviewden noemen als belangrijkste doelen voor gebruik efficiëntie en geprotocolleerde triage door de verpleegkundige. Daarnaast wordt genoemd dat gebruik de patiënt kan ontlasten en deze beter kan voorbereiden op gerichte zorg. Een aanbeveling voor verbetering van de applicatie is dat het zorgadvies aangepast zou moeten zijn op specifieke gebruikersgroepen, namelijk verpleegkundigen, huisartsen, gynaecologen, en bekkenbodemfysiotherapeuten. De voorspelde diagnose uit de applicatie wordt als betrouwbaar gezien, maar wordt meer betrouwbaar gevonden bij pure stress- of urge-incontinentie. Het programma signaleert wel risico- en complicerende factoren, maar voor een complete, zorgvuldige diagnose blijft de expertise van de uroloog naar de mening van de experts noodzakelijk. De urologen geven aan dat de vervolgadviezen voor uitgebreidere diagnose en behandeling niet altijd overeenkomen met hun eigen vervolgstappen. Dit betreft de adviezen voor aanvullend urologisch onderzoek, zoals urodynamisch onderzoek en cystoscopie. De experts geven aan dat ze zelf een ander protocol gebruiken voor het ondernemen van vervolgstappen. Een veelgehoorde aanbeveling is dan ook dat het zorgadvies aangepast zou moeten kunnen worden aan de eigen situatie (op de poli) waardoor het beter in het reguliere zorgproces geïmplementeerd kan worden.

\section{Inbedding in de eerstelijnszorg}

De meeste urologen staan positief tegenover het idee om de applicatie door huisartsen te laten gebruiken, 
nadat de patiënt de vragenlijst thuis, voorafgaand aan het consult, heeft ingevuld. Dit zou de huisarts kunnen ondersteunen bij de initiële behandeling van een over het algemeen onschuldige aandoening als UI bij vrouwen. Zodra conservatieve behandelingen geen effect hebben, is doorverwijzing naar de uroloog of een multidisciplinair samenwerkingsverband echter geïndiceerd, omdat de huisarts de aanvullende diagnostiek deels niet zelf kan uitvoeren.

\section{Zelfzorgmodule}

Over het algemeen zijn de urologen positief over het bestaan van de zelfzorgversie, hoewel ze soms vraagtekens zetten bij het effect ervan. Ze achten de applicatie vooral geschikt voor vrouwen met stressincontinentie die niet naar een huisarts willen of durven, maar die wel iets aan hun probleem willen doen. Het doel van een (internet)zelfzorgprogramma voor vrouwen met UI zou ten eerste moeten zijn het bespreekbaar maken van het probleem en educatie van de patiënt. Hierdoor wordt de zelfredzaamheid van de patiënt vergroot en zal er eerder hulp worden gezocht bij de zorgverlener. Daarnaast wordt het zorgproces efficiënter wanneer de vrouwen meer weten over de aandoening en een aantal acties (leefstijlveranderingen en bekkenbodemoefeningen) al hebben ondernomen. Aandachtspunten liggen bij de groep vrouwen met urge-incontinentie, omdat bij hen sprake kan zijn van ernstige achterliggende pathologie, die bij de screening door de applicatie gemist kan worden. Bij de aanwezigheid van risicofactoren en wanneer de zelfzorgbehandeling geen effect oplevert, moet het advies worden gegeven om naar de huisarts te gaan. De diagnose wordt betrouwbaar geacht, maar er worden vragen gesteld bij de begrijpelijkheid van de diagnose voor patiënten. Verbetering van de zelfzorgversie wordt gezien in het

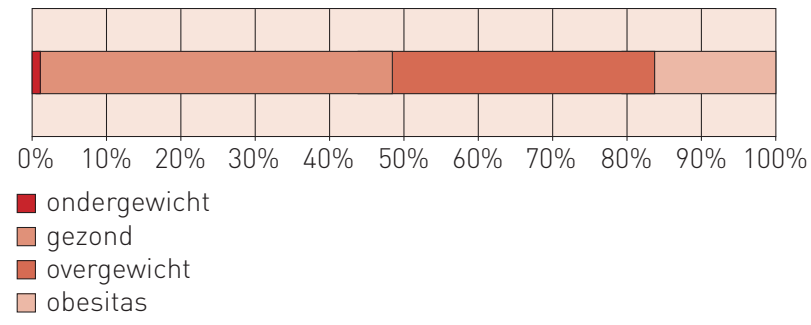

Figuur 1 Lichaamsgewicht.

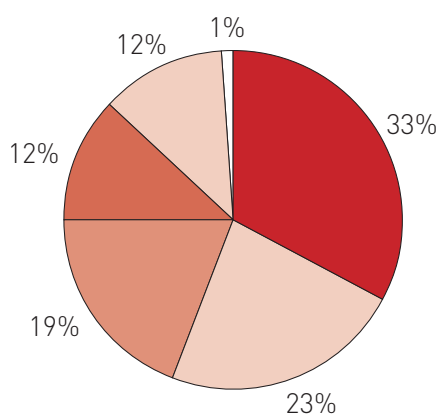

zuivere stress $\square$ gemengde stress $\square$ gemengd $\square$ gemengd urge $\square$ zuivere urge $\square$ onbekend

Figuur 2 Type incontinentie. toespitsen van het advies op de patiënt. Het advies zou moeten bestaan uit voor de patiënt relevante informatie, zoals informatie over de aandoening, leefstijlverandering en bekkenbodemoefeningen. Bij de laatste twee is begeleiding belangrijk. Een laatste kanttekening van de urologen is dat de behandeling van de zelfzorgmodule te algemeen kan zijn en daardoor niet voldoende is gericht op de specifieke problematiek van de patiënt.

\section{Kwantitatief onderzoek onder patiënten}

\section{Database zelfzorgmodule}

In de periode 16 januari 2008 t/m 24 oktober 2009 gebruikten 695 vrouwen de online zelfzorgmodule. Beantwoorden van de 45 vragen werd door $96 \%$ van de vrouwen als gemakkelijk ervaren; het merendeel was er binnen 5 minuten mee klaar. De gemiddelde leeftijd van de vrouwen was 56,9 jaar (SD 11,9). Het grootste gedeelte van de vrouwen had matig overgewicht $(35,4 \%)$ of obesitas $(16,1 \%)$ (figuur 1). Deze percentages zijn vergelijkbaar met de percentages vrouwen in deze leeftijdscategorie uit de algemene bevolking (leeftijdscategorie 45-65 jaar: matig overgewicht $32,6 \%$, obesitas 12,6\%). ${ }^{23}$ Figuur 2 geeft een overzicht van de diagnose die de zelfzorgmodule voorspelde. Bij de meeste vrouwen was de voorspelde diagnose zuivere stressincontinentie. Het overgrote gedeelte van de vrouwen was matig incontinent (figuur 3). Dit is de objectieve ernst, gemeten met vragen over frequentie en hoeveelheid urineverlies, verbandverbruik en kwaliteit van leven. Ook de invloed op de kwaliteit van leven werd door de meeste vrouwen aangegeven als 'een beetje. Toch gaf een behoorlijk aantal $(34,4 \%)$ aan dat UI een grotere invloed ('nogal', 'ernstig' en 'zeer ernstig') had op de kwaliteit van hun leven (figuur 4).

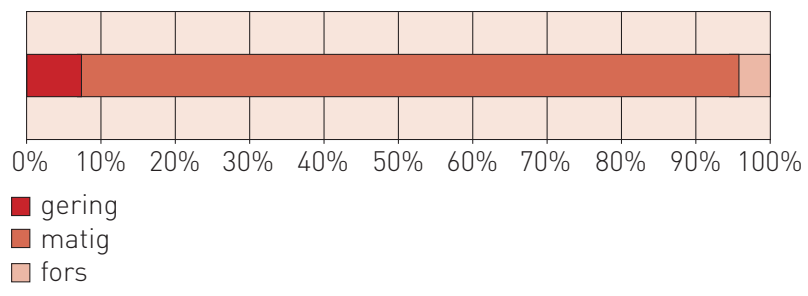

Figuur 3 Ernst van de incontinentie.

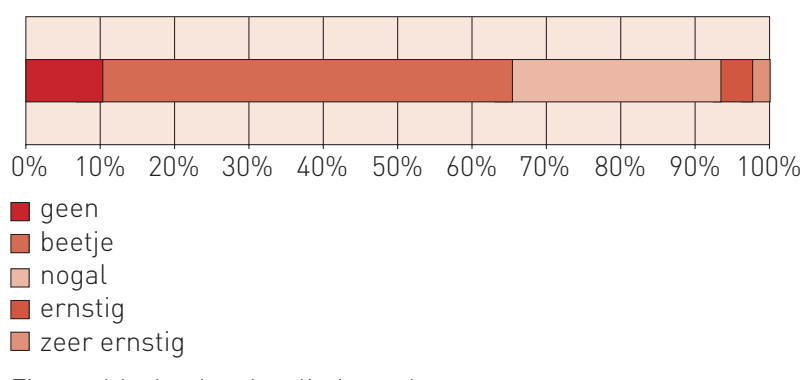

Figuur 4 Invloed op kwaliteit van leven 


\section{Survey}

De online survey werd door 32 respondenten ingevuld. Een aantal lijsten was zeer onvolledig ingevuld ( $<50 \%$ ingevuld) en een aantal respondenten had de zelfzorgmodule niet gebruikt. Uiteindelijk waren er 22 bruikbare vragenlijsten door respondenten die bleken te verschillen op de gemeten variabelen van de totale gebruikersgroep (chi-square, t-toets, $p>0,05$ ). De respondenten die de vragenlijst hadden ingevuld waren grotendeels hoger opgeleid (16\% laag, 34\% midden, 50\% hoog). Gemiddeld zaten zij 4 uur per dag op internet. De meeste respondenten kwamen via de zorgverzekeraar bij de zelfzorgmodule (63\%) en kregen het gebruik ervan vergoed (69\%). Veel respondenten hadden geprobeerd om zelf iets aan hun incontinentie te doen. 50\% had bekkenbodemoefeningen gedaan, en $18 \%$ had wel eens plastraining gedaan. Alle respondenten hadden het advies gekregen om bekkenbodemoefeningen te doen en van de respondenten die dat nog niet deden, was $90 \%$ van plan dit te gaan doen. $77 \%$ van de respondenten had het advies gekregen om een plaslijst bij te houden, hiervan was $71 \%$ van plan om dat te doen. $59 \%$ van de respondenten had het advies gekregen om plastraining te doen. Van de respondenten die dat nog niet deden, was $67 \%$ van plan om dit daadwerkelijk te doen. Over het algemeen waren de respondenten redelijk tevreden over het onlinezelfzorgprogramma (tabel 1). Het invullen van de vragen van de applicatie werd als het meest gebruiksvriendelijk ervaren. Over de inhoud van die vragen waren de respondenten minder tevreden. Zij gaven aan dat de vragen hen niet volledig in staat stelden om hun probleem goed weer te geven en zij vonden de antwoordmogelijkheden niet altijd volledig.

Bij de follow-upmeting gaven 10 van de 11 respondenten aan dat ze (bewuster) bekkenbodemoefeningen hadden gedaan. 3 Respondenten hadden naar aanleiding van het advies extra informatie over hun aandoening gezocht. 1 respondent gaf aan dat ze de plaslijst had gebruikt, 1 respondent gaf aan met vrienden of familie te hebben gepraat over haar incontinentie en 1 respondent gaf aan professionele hulp te hebben gezocht.

\section{Conclusie en discussie}

\section{Mogelijkheden en beperkingen digitale ondersteuning}

In deze studie zijn de mogelijkheden nagegaan voor digitale ondersteuning bij UI ter verbetering van de informatievoorziening aan patiënten over UI, behandelmogelijkheden en zelfzorg, ter verbetering van de bereikbaarheid van urologische zorg en ter bevordering van de zichtbaarheid van de uroloog als specialist bij de huisarts.

De onderzochte applicatie biedt mogelijkheden voor zelfzorg. Uit de interviews met experts kwam naar voren dat vrouwen met ongecompliceerde stressincontinentie de gewenste doelgroep voor zelfzorg zijn. Uit de analyse van de database van de zelfzorgmodule blijkt dit ook de grootste groep gebruikers van de zelfzorgmodule te zijn. Uit de follow-upvragenlijst bleek dat bijna alle respondenten naar aanleiding van het advies bekkenbodemoefeningen zijn gaan doen. Daarnaast is een aantal respondenten op zoek gegaan naar extra informatie en is er professionele hulp ingeschakeld. De onderzochte applicatie biedt ook mogelijkheden voor de verbetering van de informatievoorziening aan patiënten over UI en de behandelmogelijkheden. De experts geven aan dat het doel van de applicatie educatie van de patiënt zou moeten zijn. De zelfzorgmodule bevat informatie over de aandoening en behandelmogelijkheden en lijkt de op de patiënt afgestemde informatie eenvoudig en vlot te leveren (96\% van de gebruikers vond de vragen gemakkelijk te beantwoorden; het merendeel was binnen 5 minuten klaar met invullen).

Uit het onderzoek blijkt verder dat patiënten vertrouwen hebben in de verkregen informatie. Dit lijkt erop te wijzen dat de applicatie de informatievoorziening aan patiënten kan verbeteren. Uit het onderzoek komen echter ook beperkingen van online informatievoorziening en zelfzorg naar voren. De experts geven aan dat er een risico is op ernstige achterliggende pathologie bij vrouwen met urge-incontinentie. Wanneer dit risico bestaat, zou duidelijk het advies gegeven moeten worden om naar de huisarts te gaan. Ook als de zelfzorgbehandeling geen effect sorteert, moet dit advies worden gegeven. In de bestaande applicatie is dit ingebouwd, maar dit blijft een belangrijk aspect waaraan de applicatie zal moeten blijven voldoen. Verder is de begrijpelijkheid van de diagnose en het advies voor de patiënt een belangrijke voorwaarde om het doel te kunnen behalen. De geïnterviewde experts stelden vragen bij de begrijpelijkheid van de diagnose voor patiënten. Dit is echter niet bevestigd door het onderzoek onder de patiënten. Hierbij scoort de diagnose, op onderdelen als betrouwbaarheid en bruikbaarheid, relatief hoog (tabel 1). Verder geven de experts aan dat het advies toegespitst zou moeten worden op de patiënt door middel van het toevoegen van

\begin{tabular}{|c|c|c|c|}
\hline & subschalen & gemiddelde* & SD \\
\hline \multirow[t]{4}{*}{ bruikbaarheid ( $\alpha=0,75$ ) } & & 3,81 & 0,22 \\
\hline & Algemeen & 3,62 & 0,44 \\
\hline & Vragen & 4,08 & 0,37 \\
\hline & Advies & 3,73 & 0,29 \\
\hline \multirow[t]{4}{*}{ kwaliteit van zorg $(\alpha=0,96)$} & & 3,18 & 0,71 \\
\hline & Vragen & 2,69 & 1,01 \\
\hline & Diagnose & 3,51 & 0,65 \\
\hline & Advies & 3,34 & 0,63 \\
\hline
\end{tabular}

* Gemeten met een vijfpunts Likert-schaal $1 \mathrm{t} / \mathrm{m} 5$ (1 = zeer negatief, 5 = zeer positief). 
informatie over de aandoening, leefstijlverandering en bekkenbodemoefeningen. In de zelfzorgmodule wordt deze informatie gegeven, maar is er ruimte voor verbetering van de presentatie van de informatie. De patiënten geven aan dat de vragen uit de zelfzorgmodule hen niet volledig in staat stellen om hun probleem goed weer te geven en ze vinden de antwoordmogelijkheden niet altijd volledig. Dit is een beperking van een volledig geautomatiseerd systeem, waarin geen open vragen kunnen worden opgenomen. Bij de ontwikkeling van de applicatie is ervoor gekozen om de vragen en antwoorden te beperken tot onderdelen die een bijdrage leveren aan de algoritmen ter voorspelling van de diagnose. Een manier om dit probleem op te vangen is het toevoegen van de mogelijkheid tot e-consultatie. Echter, hierdoor verdwijnt het volledig geautomatiseerde karakter van de applicatie en is de inzet van een specialist noodzakelijk. Een andere belangrijke beperking van de zelfzorgmodule die door de experts wordt benoemd, is dat de behandeling onvoldoende is gericht op de specifieke problematiek van de individuele patiënt. Deze beperking kan worden gezien als een grens van de applicatie; de applicatie geeft een basisbehandeling die is afgestemd op de kenmerken en klachten van de patiënt. Bij meer gecompliceerde gevallen is deze zorg niet voldoende en zal de meer specialistische zorg van de uroloog moeten worden gezocht.

Het tweede aspect dat is onderzocht, is het verbeteren van de bereikbaarheid van urologische zorg voor vrouwen met UI. Uit dit onderzoek komt naar voren dat deze verbetering bereikt zou kunnen worden door de huisarts digitale ondersteuning te bieden in de vorm van de onderzochte applicatie. Wanneer de huisarts middelen tot zijn beschikking heeft om op eenvoudige wijze een diagnose te voorspellen en naar aanleiding hiervan een basisbehandeling kan starten, kan dit urologische zorg voor vrouwen met UI dichterbij brengen. Daarnaast zou inbedding van de applicatie in de reguliere urologische zorg ervoor moeten zorgen dat de zorg efficiënt en geprotocolleerd verloopt wanneer verwijzing naar specialistische urologische zorg is geïndiceerd. Belangrijke aandachtspunten hierbij zijn de overeenstemming van het protocol van de applicatie met het protocol dat wordt gehanteerd op de poli waar de applicatie wordt gebruikt, het aanpassen van het advies aan de gebruiker (huisarts, verpleegkundige, uroloog) en het onderkennen dat de applicatie moet worden gezien als een aanvulling op de reguliere zorg en geen vervanging beoogt te zijn.

Het derde punt is dat digitale ondersteuning gericht zou moeten zijn op het verbeteren van de zichtbaarheid van de uroloog als specialist bij de huisarts. Dit lijkt bereikt te kunnen worden door het inzetten van de applicatie bij de huisarts. Zoals de experts hebben aangegeven, is het belangrijk om, wanneer dit noodzakelijk is, de huisarts te adviseren de patiënt naar de uroloog door te verwijzen. De applicatie voorziet hierin en zal de zichtbaarheid van de uroloog en het geven van adequate zorg positief beïnvloeden.

\section{Beperkingen van het onderzoek}

Bij het interpreteren van de resultaten moet rekening gehouden worden met een aantal beperkingen van het onderzoek. Ten eerste zijn de resultaten van het kwantitatieve deelonderzoek gebaseerd op de volledig ingevulde vragenlijsten van 22 vrouwen die de zelfzorgmodule hebben gebruikt. Dit is maar een klein percentage van het totale aantal gebruikers van de applicatie. Dat de survey maar door 22 vrouwen volledig was ingevuld komt mogelijk doordat de survey kon worden bereikt via een link onderaan het advies dat de gebruikers van het zelfzorgprogramma kregen. Het was niet verplicht om de survey in te vullen en er werd ook geen beloning tegenovergesteld. De reden dat de survey niet prominenter in de applicatie aanwezig was en er geen verplicht onderdeel van uitmaakte, was om de applicatie zo laagdrempelig mogelijk te houden. Een beperking die voortkomt uit het geringe aantal respondenten is de verminderde generaliseerbaarheid. We kunnen niet met zekerheid zeggen dat de resultaten generaliseerbaar zijn naar alle mensen die de applicatie hebben gebruikt, al hebben we geen significante verschillen tussen deze groepen gevonden. Ook de generaliseerbaarheid naar de bredere populatie vrouwen met UI is niet vast te stellen. Een laatste beperking van het onderzoek is dat er geen effectmeting is gedaan. We hebben de mogelijkheden voor digitale ondersteuning via ervaringen en visies van gebruikers en experts onderzocht. In een vervolgonderzoek kan worden nagegaan of de zorg via een dergelijke ondersteuning effectiever kan verlopen dan traditionele zorgverlening.

\section{Implicaties voor de zorg}

Ondanks de hiervoor benoemde beperkingen, denken we dat dit onderzoek laat zien dat er wel degelijk mogelijkheden zijn voor digitale ondersteuning voor vrouwen met UI. Het lijkt erop dat poliklinische triage met behulp van een digitale applicatie het mogelijk maakt om gerichte zorg te bieden en een kwaliteitsimpuls kan leveren. Het inzetten van een aangepaste versie van dezelfde applicatie in de eerstelijnszorg kan ervoor zorgen dat goede urologische zorg voor vrouwen met UI beter bereikbaar is. Daarnaast kan laagdrempelige informatievoorziening en het bieden van zelfzorgmogelijkheden via een op de patiënt toegespitste applicatie taboedoorbrekend werken en dienen als een eerste stap in de behandeling. Via de huisarts kan de uroloog worden ingeschakeld wanneer zijn specialistische zorg vereist is.

Literatuur

1. Wennberg AL, Molander U, Fall M, et al. Lower urinary tract symptoms: lack of change in prevalence and help-seeking behaviour 
in two population-based surveys of women in 1991 and 2007. BJU Int. 2009;104(7):954-9.

2. Boyle P, Robertson C, Mazzetta C, et al. The prevalence of lower urinary tract symptoms in men and women in four centres. The UrEpik study. BJU Int. 2003;92(4):409-14.

3. Lasserre A, Pelat $C$, Gueroult $V$, et al. Urinary incontinence in french women: prevalence, risk factors, and impact on quality of life. Eur Urol. 2009;56(1):177-83.

4. Hannestad YS, Rortveit G, Sandvik H, Hunskaar S. A communitybased epidemiological survey of female urinary incontinence: The Norwegian EPINCONT Study. J Clin Epidemiol. 2000;53(11):1150-7.

5. Vandoninck V, Bemelmans BLH, Mazzetta C, et al. The prevalence of urinary incontinence in community-dwelling married women: a matter of definition. BJU Int. 2004;94(9):1291-5.

6. Norton PA, Macdonald LD, Sedgwick PM, Stanton SL. Distress and delay associated with urinary-incontinence, frequency, and urgency in women. BMJ. 1988;297(6657):1187-9.

7. Hunskaar S, Lose G, Sykes D, Voss S. The prevalence of urinary incontinence in women in four European countries. BJU Int. 2004;93(3):324-30.

8. Van Gemert-Pijnen J, Karreman J, Seydel E. Schaamte, onbekendheid en onbegrip hinderen adequate behandeling van urologische aandoeningen. Nederlands Tijdschrift voor Urologie. 2008;16:S7-S13.

9. Hagglund D, Wadensten B. Fear of humiliation inhibits women's care-seeking behaviour for long-term urinary incontinence. Scand J Caring Sci. 2007;21(3):305-12.

10. Da Silva L, Lopes M. Urinary incontinence in women: reasons for not seeking treatment. Rev Esc Enferm USP. 2009;43(1):68-74.

11. Shaw C, Tansey R, Jackson C, et al. Barriers to help seeking in people with urinary symptoms. Fam Pract. 2001;18(1):48-52.

12. Penning-van Beest FJ, Sturkenboom MC, Bemelmans BL, Herings $\mathrm{RM}$. Undertreatment of urinary incontinence in general practice. Ann Pharmacother. 2005 Jan;39(1):17-21.

13. Deskundigencommissie Incontinentie (DINC) in opdracht van het College voor Zorgverzekeringen (CVZ). Attentie voor Incontinentie. 2006.

14. Wansink W. De beste urologen, loodgieters van de vergrijzing. Maarssen: Elsevier; 2007. Beschikbaar via: http://www.elsevier.nl/web /10127975/Dossiers/Uw-Gezondheid/De-beste-artsen-enziekenhuizen/De-beste-urologen,-loodgieters-van-de-vergrijzing.htm.

15. Evenblij M. Meer dan een plasprofessional. Medisch Contact. 2008;63(11):458-61.

16. De Bruin M, Waard W de, Leliefeld H, et al. Multicenter-validatie van het internetdiagnose computer programma MediArts voor urineincontinentie bij vrouwen. Nederlands Tijdschrift voor Urologie. 2006;6:176.

17. De Bruin M, Leliefeld H, Zambon V. The value of the online diagnosis programme 'mediarts 1.7 ' for female urinary incontinence. Eur Urol Suppl. 2005;4(3):91.

18. De Bruin M, Bentvelsen F. The 'Mediarts' test for female urinary incontinence reduces the need for invasive urodynamics. Eur Urol Suppl. 2007;6(2):203.

19. Patton MQ. Qualitative evaluation and research methods. 2nd ed.Thousand Oaks, USA: Sage Publications Inc.; 1990.

20. Brooke J. SUS - A quick and dirty usability scale. In: Jordan PW, et al. Evaluation in Industry. Londen: Taylor \& Francis; 1996. pp. 189-94
21. Lewis JR. IBM Computer Usability Satisfaction Questionnaires Psychometric evaluation and instructions for use. Int J Hum Comput Interact. 1995;7(1):57-78.

22. Donabedian A. The quality of care - How can it be assessed? Arch Pathol Lab Med. 1997;121(11):1145-50.

23. Medicine Io. Crossing the quality chasm: A new health system for the 21st century. 2001.

24. Centraal Bureau voor Statistiek. Zelfgerapporteerde medische consumptie, gezondheid en leefstijl. Internet: http://statline.cbs.nl.

\section{Commentaar}

M.R. van Balken

\section{Afdeling Urologie Rijnstate Ziekenhuis, Arnhem}

In tijd van enkele jaren heeft het gebruik van nieuwe, 'social' media een grote vlucht genomen, niet in de laatste plaats in de zorg. Volgens een recent rapport uit de Verenigde Staten van Amerika zoekt ruim meer dan de helft van de volwassen populatie informatie over haar gezondheid via het internet. Daarnaast is er een trend, opgedrongen door de overheid, zorg meer en meer vanuit de tweede lijn naar de eerste lijn, of liever nog, naar zelfzorg te verplaatsen.

De auteurs mogen dan ook geprezen worden voor hun vooruitziende blik. De door hen beschreven, intussen vercommercialiseerde internetapplicatie werd al in 2005 internationaal gepresenteerd en speelt bij uitstek in op de hiervoor genoemde ontwikkelingen. Bovendien is het onderwerp incontinentie door de 'taboesfeer' waarin zij zich bevindt extra geschikt voor het anonieme karakter van een dergelijke applicatie.

Helaas valt er op de wetenschappelijke waarde van het artikel wel wat af te dingen. Een deel van het artikel is gebaseerd op de expert opinion van slechts 5 urologen (en in het kader van full disclosure: daar was ik er één van), het belangrijkste deel op 22 vragenlijsten van 32 gebruiksters uit een totaal van 695 vrouwen. Van deze vrouwen bleek het grootste deel hoger opgeleid en zat het gros gemiddeld 4 uur per dag op internet. De representativiteit is derhalve, zoals de auteurs in hun tekst zelf ook al aangeven, bediscussieerbaar. Daarnaast gaat het voor wat betreft de zelfzorgmodule eigenlijk alleen om een soort gebruiksvriendelijkheidsonderzoek: impact op wat het uiteindelijk gedaan heeft voor de incontinentie komt eigenlijk niet (voldoende) aan bod. Sterker nog, uitspraken over sensitiviteit, specificiteit of voorspellende waarde kunnen met dit artikel niet worden gedaan. Desalniettemin ligt hier voor de toekomst wel een uitdaging. Hoe kunnen wij meegaan in de onomkeerbare informatiebehoefte en wens tot zelfvoorziening van een groeiende groep patiënten, zonder tekort te doen aan het belang van professionaliteit en expertise van de uroloog. En hoe vergeten we daarbij niet de vaak oudere, misschien wat minder ontwikkelde patiënt, die niet de beschikking heeft over bedoelde informatiebronnen. De auteurs hebben met hun artikel in ieder geval de eerste stapjes gezet. 